\section{Handbok med stor breidde om intensiv- medisinske problemstillingar i hematologi}

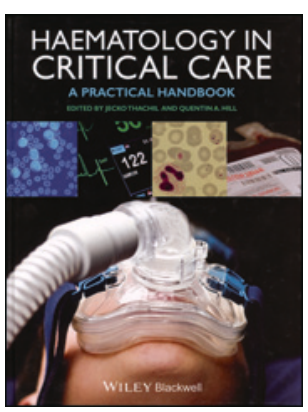

\author{
Jecko Thachil, Quentin A. Hill, red. \\ Haematology in critical care \\ A practical handbook. 254 s, tab, ill. \\ Chichester: Wiley-Blackwell, 2014. \\ Pris GBP 62 \\ ISBN 978-1-118-27424-8
}

Berre 1-2\% av pasientane i intensivavdelingar har ein hematologisk grunnsjukdom, men mange av intensivpasientane har avvikande hematologiske prøvar, trombose eller bløding. Forfattarane har som mål at boka skal vere ei handbok og kjelde for ekspertråd ved hematologiske problem hos intensivpasientar og for behandling av akutte tilstandar hos hematologiske pasientar.

Dei to redaktørane arbeider ved sjukehus i Leeds og Manchester. Dei fleste av 41 andre bidragsytarar har også sitt virke i Storbritannia, men nokre få er frå USA og India. Fagbakgrunnen til forfattarane er hematologi, intensivmedisin eller transfusjonsmedisin. Barnelegar er representert med ein seksjon om hematologi i pediatrisk og neonatal intensivbehandling.

Boka er delt inn i 10 seksjonar og 35 kapittel. Den startar med avvikande hematologiske prøvesvar og grunnar for dette. Deretter fylgjer mellom anna seksjonar om koagulasjonsproblem, transfusjonsproblem, hemoglobinopatiar i intensivmedisinsk samanheng, nøytropen feber, komplikasjonar etter stamcelletransplantasjon og tiltak for å førebyggje multiorgansvikt hos den ustabile pasienten. Samtidig er det viktig å overføre pasienten tidleg nok til intensivbehandling, og dette er drøfta i eit eige kapittel. I siste kapittelet er akutte komplikasjonar, som til dømes tumorlysesyndrom, omtala.

Oppfyller boka målsettinga? Boka er på mange felt god for den som treng eit raskt oversyn over eit vidt spekter av hematologiske og intensivmedisinske problemstillingar. Den retter seg mot legar som arbeidar innanfor ulike fagområde, og relevansen og nytten av ulike kapittel vil nok variere avhengig av fagleg bakgrunn. Bruken av referansar og evidensgrunnlaget for råd som blir gjevne, varierer. For det meste har redaktørane klart å unngå for mykje overlapping mellom kapitla. Eitt unntak er rekombinant faktor VIIa, som ved gjennomlesing av heile boka kan irritere lesaren. Men for ei bok kor lesaren ofte vil lese einskilde kapittel, må det finnast tilgjeving for det.

Boka har to tekstspalter på kvar side, og ein del tabellar og einskilde algoritme har fătt plass, men nesten ingen bilete. Bruk av til dømes bilete av blodutstryk og ikkje berre tekstskildring, og meir bruk av faktaboksar, ville gjort innhaldet lettare tilgjengeleg for lesaren.

Eg vil tilrå boka for legar som arbeider med blodsjukdommar eller intensivmedisin, og som treng oversyn over eit vidt spekter av hematologiske intensivmedisinske problemstillingar.

\section{Anders Vik}

Seksjonsoverlege, Hematologisk seksjon

Medisinsk klinikk

Universitetssykehuset Nord-Norge

\section{Eksamenshjelp}

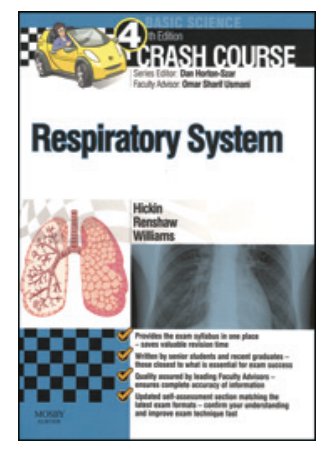

Sarah Hickin, James Renshaw,

Rachel Williams

Crash course - Respiratory system

4. utg. 230 s, ill. Edinburgh: Mosby Elsevier, 2013. Pris GBP 26

ISBN 978-0-7234-3627-0

En student spurte en gang sin professor i anatomi om han kunne definere pensum til eksamen. Ja, det er lett, svarte professoren, alt fra issen til fotsålen. Vi har alle vært der hvor vi prøver å forberede oss til eksamen og har en ubehagelig følelse av at vi ikke har oversikten over et diffust, løst definert pensum. Det er da desperasjonen kan overstige høyden til bokstabelen på lesesalen.

Her kommer bokserien «Crash course» inn med sitt tilbud av korte, konsise bøker beregnet på studenter som ønsker å repetere kunnskap før ulike medisinske avgangseksamener. Bøkene er skrevet $a v$ studenter/nylig uteksaminerte leger for studenter.

Respiratory system inngår i denne serien. Tre rykende ferske leger og en akademisk lærer er ansvarlige for denne fjerde utgaven. I forordet står det at de ønsker en «bench to bedside»-tilnærming ved å integrere basal kunnskap med klinisk praksis. Boken er inndelt i tre hovedavsnitt: først 70 sider med basal anatomi og fysiologi, deretter 40 sider som omtaler klinisk tilnærming til lungepasienten, for å avslutte med 80 siders omtale av de vanligste kliniske tilstandene. De korte kapitlene har mange overskrifter og figurer. Figurene er enkle, tofargede strektegninger, røntgenbilder eller fotografier. Boken er oversiktlig og lett å finne frem i. Figurene er generelt velvalgte og lette å forstå. En del steder er det henvist til internettsider med veiledninger (guidelines). Boken avsluttes med 20 sider med testspørsmål.

Å skrive en god lærebok er ikke lett. Ved siden av pedagogiske kvaliteter kreves det at forfatteren har en god og oppdatert oversikt over fagfeltet. $\AA$ skrive et sammendrag, der bare det essensielle skal være med, er enda mer krevende. Spørsmålet er om den som akkurat har avlagt en eksamen, har en slik oversikt. I den aktuelle utgivelsen er dette dilemmaet forsøkt løst ved at en seniorlærer ved National Heart \& Lung Institute i London, Omar Usmani, har veiledet forfatterne. Den bærer likevel preg av en til tider springende, usammenhengende tekst.

Boken er fra 2013, men flere av kapitlene er ikke oppdatert til dagens kunnskap. Den siste inndelingen av kols i ulike fenotyper er for eksempel ikke kommet med. Lungekreftkapitlet har en tabell om TNM-klassifisering som var aktuell for 2009, men ikke i dag. Engelske forhold er naturlig nok vektlagt, noe som medfører at norske studenter ikke alltid vil kjenne seg igjen.

Konklusjonen er at denne boken kan være aktuell for dem som har tid til enda en bok, men den er ikke egnet til å lære og forstå et fag. Som repetisjon den siste uken før eksamen kan den kanskje være til hjelp, men problemet er at det ujevne innholdet ikke alltid er aktuelt for en norsk student.

\section{Lars Fjellbirkeland}

Førsteamanuensis, spesialist i lungemedisin, Universitetet i Oslo 